\title{
Religious Fanaticism, a Threat to National Security: The Case of Boko Haram Sect
}

\author{
Patrick Nmah*
}

\section{Abstract}

The study examined the effects of Boko Haram terrorist activities in Nigeria and the strategies the Nigerian law enforcement agencies should employ to contend the situation. The purpose of this research work is to highlight and educate the populace on the negative tendencies of this group and the approach the federal government should use to end this group's threat to national unity. It is discovered that this group insurgency is as a result of unemployment, religious bigotry and hatred it has for western civilization. The method of approach is historical with review of relevant literature such as books, journals coupled with materials from archives. The research work recommends that superior power among other means should be employed to extinct this group and similar ones in Nigeria and beyond. This is because, until Jesus returns (Dan. 9:26; Matt. 24:6), there are some people so deeply committed to doing evil that they can be restrained, not by dialogue, argument, reason and persuasion, but only by superior force.

http://dx.doi.org/10.4314/ujah.v13i1.7

\section{Introduction}

Great social thinkers such as Karl Marx, Engels, Nietzsche, Lenin and David Hume have postulated the 'death' of religion in the face of philosophy, economy and improved standard of living condition of humans. The argument holds that suffering and social hardships make religion relevant in the society. Marx, in fact, canvassed for the abolition of religion because it is illusory to genuine human happiness. According to Wilson (1982) and Weber (2002), secularization theory holds that Christianity, with its value centered on the promotion of 
Western education, intrinsically brings about rationalization independence in thought - which naturally reduces the significance of organized associations such as religion. For Marx, religion is the "sigh of the oppressed," the "opium of the people" which abolishment can only occur by emancipation from "the estranged world of human objectification" (Tucker, 1978). Huntington (1996) has said,

That the emerging civilization especially from the Arab world and the communist China would pose serious challenges to Western civilization. "The West is and will remain for years to come the most powerful civilization. Yet its power relative to that of other civilization is declining. As the West attempts to assert it values and to protect its interests, non-Western societies confront a choice. Some attempt to emulate the West and to join or to "band-wagon" with the West. Other Confucian and Islamic societies attempt to expand their own economic and military power to resist and to "balance" against the West. A central axis of the post - Cold War World politics is thus the interaction of Western power and culture of non-Western civilization" p. 29).

In Nigeria especially, religion plays a vital and influential role in the society that was manifested itself as a potent force in the political development of the Nigerian state from preindependence to post-independence. For Falola (1990), Kukah (1994), Kenny (2006) and Suberu (2009), hardly can the Nigerian state be talked about without reference to religion. The Jihad, the civil war propaganda, the Sharia law controversy, the tensions provoked by the Nigerian accession to the Organization of Islamic countries now organization for 
Islamic corporation and the incessant religious crisis that have engulfed the Northern Nigeria indicate religion cannot be ignored or wished away in the Nigerian political development; thus, the "Maitatsine" and "Boko Haram" sectarian riots of December 1980; and 2009-2011 - respectively.

National security is highly valued by the people of Nigeria and their co-operation with defense agents whenever national security is threatened tends to lend credence to this. What is sometimes a subject of controversy is how much should be allocated to defense in view of the fact that there are other pressing national needs such as the provision of free education, medical services, employment, good network of roads, energy, and essential civilian consumer goods, which require also substantial amount of resources to be committed to their provision. The insurgent Boko Haram and its like have given rise to the question of how much to be provided for defense in recent time.

Nigeria needs modern sophisticated armored tanks, fighter helicopters and vehicles, armored personnel carriers, artillery guns, surface to surface and surface to air missiles, combat air crafts, trained security forces and the like. Okeke (1990) tacitly argued whether with the military hardwares Nigeria has, can we conveniently say with assurance that Nigeria is well equipped to defend her national sovereignty in case of any internal and external aggression such as that of Boko Haram, Niger Delta militancy, armed robbery, kidnapping, and other evil machinations.

It is the aim of this paper to study the efficacy of using superior power (the civil authority) to eradicate terrorism and other violent criminalities in Nigeria. In the course of this research, we shall be using Boko Haram and Yusufiyya interchangeably. We shall rely on primary and secondary sources, which include articles, books, archives and libraries in this research work. The purpose of this research work is to 
expose the danger of this Boko Haram and its likes and proffer solutions in order to contend them.

\section{Conceptual Framework}

Enuka (2010) citing Barnes opines that a universally accepted definition of terrorism has been difficult owing to reasons of politics rather than semantics. The aphorism "one man's terrorist is another man's freedom fighter" underscores how the use of terrorism can be highly subjective, depending upon one's sympathies (Hoffman, 2000). Terrorism could be defined as the deliberate creation and exploitation of fear for bringing about political change. The acts are often by non-governmental groups or individuals not officially serving governmental agencies. To justify their use of violence, terrorists argue that they have been excluded from or frustrated by, the accepted process of bringing about political change. Added to the individual groups' terrorism there is also state terrorism. State terrorism refers to state-sponsored terrorist operations targeted at the furtherance of a state's foreign policy. Religious fanaticism denotes religious extremism, which in other words is an irrational attitude to religion which leads the religionist to the practice of religion beyond the bounds of reason and, therefore, without moderation (Nmah, 2004). In this context, religious fanaticism should be seen to mean the same thing as terrorism.

Terrorism poses a great threat to the international security in term of destruction of lives and property. The terrorist attack on the World Trade Center and Pentagon resulted in the death of over three thousand persons. In economic terms, Fromkin (2004) states that the direct cost of the September 11 attack has been estimated at 27.2 billion US dollars, and with indirect cost estimated at 500 billion dollars. Many states of the world have incurred lots of loses in their over-all economic growth and development arising from the ugly incidence of terrorism. Terrorism has impacted negatively 
on national economies through increase in military and security spending.

Security on other hand can be conceived in terms of either conventional security doctrine or alternative security doctrine, depending on whether one is toeing the Realist or Idealist theoretical perspective (Enuka, 2010). Adherents of political realism advocate conventional security which places emphasis on military and strategic concerns. This position which limits the concept of security to the domain of military matters is shared by the likes of Al-Mashat who maintain that security is concerned solely with the military aspects of the nation, strategic issues of the super powers, and alliancebuilding process (Onoja, 1998). On the other hand, the proponents of the Idealist theory do not share this view, but stress on the alternative security doctrine which emphasizes such imperatives as food, shelter, health, employment, security of lives and property, equitable distribution of national resources, strong political institution, strong educational institution, strong political institution, strong electoral institution, moral and intellectual spiritual citizens coupled with functional social cohesion.

Irrespective of the ambiguity that characterize the definition of terrorism and its concomitant killings and damages especially the way it has become prevalent today in Nigeria and other African countries hurts to no small measure in individuals' and states' protection and, therefore, portends dangerous consequences to the global security. The name Boko Haram means Western education as a sin, and the group wants to overthrow Nigeria's government. The group is also known as Taliban, although no one can emphatically associate any links to that of Afghanistan. Boko Haram is an Islamic fundamentalist group that advocates the replacement of state secular laws with Islamic law. It holds that the problems of the world stem from secular influences. The Shiites and Sunni religious conflicts since the $7^{\text {th }}$ century created an opening for 
radical ideologists, such as AIi Shariati (1933-77) to merge social revolution with Islamic fundamentalism, as exemplified by Iran in the 1970s. The insurgence of Boko Haram of recent is a pointer. This group is notorious for kidnappings, raping, intimidation, and molestation and known to be antiestablishments. For this group, western education is Haram, Hausa word for sin and its adherents are taught that it is their duty, as pure Muslims, to cleanse society of all influences of western education and replace it with Sharia. According to them, they argued that western education is the source of corruption, inequality and must be forbidden. Believed to have started in Maiduguri, the capital of Borno state, an ardent Boko Haram member must be ready to pay the supreme price to defend this course. Many of the members tore their degree, HND, and other certificates and renounced western values, as a demonstration of their faith. They and their like often use robbery, terrorism and rapping as a conventional strategy, not necessarily for Islamic course, but to attract attention to themselves and also to achieve their inordinate ambition.

The earliest known sects (ta'ifa) in Islam are perhaps the Sunni and the Shi'a (Shiites). Whereas the Sunni believe in integrating religion and society by adopting religion to state structures, the Shites believe in religious puritanism such that Islam must be practiced in its pure form and must be guarded from being adulterated by the society. Secondly, there is also a controversy over the origin of their caliphs' representatives of the prophet of Islam. Whereas the Sunni have designated family roots that would always produce the caliphs or imams, the Shi' a believe that the position of imam can even be earned by commoners who have excelled in religious teachings and traditions. Since the Sunni adopted religion to social structures, they have also accepted and respected political authority. Sunni leaders can function both as religious and political leaders. The Emirate systems of administration actually derive from the Sunni tradition. According to Khuri (1999), Shi'a 
sources always depict their Imams as 'the wretched,' 'the tortured,' 'the humble poor,' 'the worshippers of God' and 'the followers of his religion'. By contrast, the imam's enemies are depicted as 'the usurpers of power,' 'the religiously corrupt,' 'money mongrels,' 'the worshippers of gold' (p.40). To this day, the Sunni and the Shiites have continued to engage themselves in fratricidal wars over the origin of their caliphs or imams. This violence (or terrorism) which has now been institutionalized as part of their culture has been of an indefinable magnitude between a ruling class (Sunni) and the majority Shiites in Iraq, Yemen, Somalia and Bahrain where millions have been sacrificed to death as a result of sectarian violence between the Sunni and the Shiites. A report considers that 85,694 persons have lost their lives in Iraq over a period of four years as observed in official death certificates by the Ministry of Health in Iraq (the Guardian, Thursday, October 13, 2009, p. 11).

There are different Islamic sects in Nigeria among which are the Derika, the Izala, the Kaulu (Kablu), the Muslim brothers, the Tijjaniya and the Quaddiriya, the Shiite, the Muslim Brotherhood, and several other splinter groups. In the context of these groups threatening the survival of the Nigerian nation informed this research work on sheathing the sword (Matthew 26:52a) for Boko Haram ta' ifa: a threat to national security.

\section{Context of Interpretation}

Matthew 26:52a (NRSV)

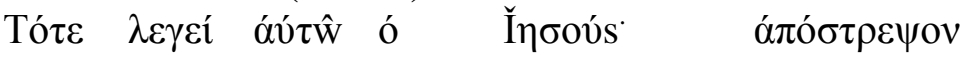

Then says to him - Jesus: Put back

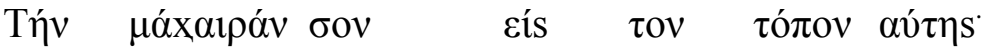

The sword of thee into the place of it:

In this context, one of Jesus' companions, Peter (Jn. 18: 10), cut off the ear of Malchus, servant of the high priest. Peter 
aimed at Malchus' head, but missed and only succeeded in "cutting off his ear". The injunction given by Jesus to his would be defendant, identified by the fourth evangelist with

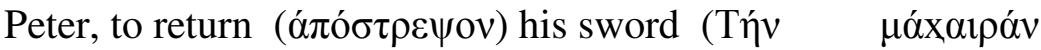

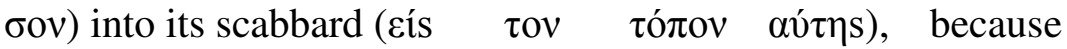
any attempt to offer forceful resistance under the present circumstances would be suicidal, is also recorded only in this gospel. This precept should be interpreted with reference to the context in which it is found, and not regarded, as Christian pacifists have often regarded it, as a general rule binding upon Christians in all circumstances. It is not in fact true that those who take the sword always die by the sword (Tasker, 1981).

The New Testament church included many soldiers serving on active duty and saw nothing morally inconsistent with Christians serving as military professionals. The conversion of Cornelius, a Raman centurion, was confirmed by the Holy Spirit with no question of his profession compromising his faith (Acts 10). John the Baptist responded to soldiers in a way that implied they were serving in a morally legitimate profession (Luke 3:14). And when Paul was imprisoned in Rome, many in the Praetorian guard became Christians (cf. Phil. 1:13). Consequently Christians soon came to fill the Roman "fortresses," military "camps," and army "companies" (cf. evidence provided by Tertullian in Apology 37; C.AD 200), and the first persecutions of the church arose because of the high number of Christians serving in the Roman army. In as much as some early Christians opposed military service (cf. Tertullian and Origen), the majority tradition of the church has never considered military service to be inconsistent with biblical standards. The heavenly father does not love enemies as he loves friends, he cannot love enemies with a love of complacency as he loves the obedient and holy. He makes his sun to rise on the evil and the good, and sends rain on the just and the unjust (Matt. 5: 43-48). So we should love 
our enemies, and gladly do them good; but this does not mean that we ought to love them as we love our friends.

\section{Hermeneutical Significance of Matthew 26:52a to Contend Boko Haram}

In our nascent democracy, we have witnessed the tendency of many people investing in violence what Judas, the Jews, and Roman soldiers armed with swords, staves or clubs intend to destroy Christ. These people were not regular troops, but a tumultuous rabble. If they had been ten times as many, they could not have taken him had he not yielded. They came from the chief priests, and elders of the people without warrant from Pilate, the Roman governor. Jesus has the ability to call on angelic legions, the joining forces with the righteous, but he did not until what the scriptures spoke about the man of lawlessness (2Thess 2:3, 9). It may be seen as modern Armageddon (Rev 16:16). And this pattern of violent has unfortunately become the most ubiquitous defining expression of our political actors. The recent political killings in Kaduna, Jos, Maiduguri, Bauchi, and Akwa-Ibom states testify to this. There is the need for us to recall that the military ruled this country Nigeria for almost fifteen years at a stretch. Military rule is characterized by dictatorship and the politics of monopoly and exclusion. Since the military rules by decrees, all avenues for the legitimate expression of grievances are always blocked. The result is that during the military, people always tend to retreat into their ethno-religious and sectional cocoons, emphasizing primordial interests and loyalties as the basis for their social mobility (Tanko, 2007). When dictatorship is dislodged and democracy comes on stage, it is these primordial interests and loyalties that normally register themselves in the political spectrum. This is partly to a greater extent why the religious primordial platform of organization and expressions such as Yusufiyya, Maitatsine and so on seem 
to be dominant in the northern part of Nigeria vis-à-vis North and South Sudan.

Long before the military incursions, the politics of monopoly and exclusion had been a dominant part of the political machinery of the ruling class in the northern part of the country. According to Tanko (2007), the basis for the establishment of the caliphate in Northern Nigeria was to promote the hegemony of the ruling class prefixed on the veneer of the Islamic religion. The Jihad of Usman Dan Fodio accelerated and consolidated the establishment of the Fulani ethnic group. He was a devout Muslim whose first interest was the study of the Quran and Muslim law. He was intent on removing the paganism that characterized so much of the Islam professed in Gobir and other Hausa states (Boer, 2006). He became a military leader, organized a Jihad, and with his Fulani herdsmen defeated the Gobir King Yunfa and his army. The colonial masters who perceived of this group as having a well-organized system of administration, and in order to make their (British people) presence (or colonial occupation) attractive to the Fulanis, facilitated the hoisting of and imposition of the members of this ethnic group over the minority groups in the region. This approach of colonialism invariably affected other parts of Nigeria. The persistent resistance of such imposition by the minority ethnic groups up to this day has always led to conflicts, and violent criminalities as could be seen in Northern Nigeria.

Since the Hausa-Fulani had always held the reins of political, cultural, religious and socio-economic power, the minority groups (largely Christians and animists), have always been made to play the second in fiddle in the socio-economic, cultural, religious and political arrangement of the region. This role allotted to the minority groups has not been a comfortable one especially given that they are the work force in the region. The consequent of all this is that conflicts and violent crimes have now been incorporated into the vocabulary of many 
Nigerians especially in the north. Violent criminalities such as that of Niger Delta Militancy, religious bigotry or intolerance, Boko Haram terrorist attacks, and the like have become tools for negotiation made prominent during the military, Musa Yar'Adua and Goodluck Jonathan era. The nature of conflict in the north is centered on religious intolerance, political, economic, and ethnic and at times for grazing/farming land. In the South, it is the issue of resource control and youth restiveness.

This nature of conflict has continued to manifest in the ethno-religious conflicts that we have been witnessing. It is for this same reason that we have witnessed the emergence of ethnic militias such as the O'dua People's Congress (OPC), the Ijaw Youth Congress, the Movement for the survival of Ogoni People (MOSOP), the Movement for the Actualization of Biafran Republic (MASSOB), and so on. Ethnic and religious nationalism rather than patriotism has also led to the call for what some Nigerians called, "Sovereign national conference" or "National Conference". When the colonialists created the Northern, Eastern and Western regions of Nigeria in 1946, each with its separated authority, ethnicity was further entrenched into the system especially, given the fact that the three regions were made up of the three major language groups (Hausa, Igbo and Yaruba). This gave room for the struggle over power between the three regions. Political parties were formed along this line. The National Council of Nigeria and the Cameroon (NCNC) was for the Eastern region and was headed by Nnamdi Azikiwe. Action Group (AG) is a splitter group of NCNC and was headed by Chief Obafemi Awolowo. And then Northern Peoples Congress (NPC) which belonged to the North and its leader was Sir Ahmadu Bello. Thus ethnic loyalty was reinforced and the ethnicization of politics introduced.

On religious aspect, the Muslim for example, called non-Muslim "Kafir" (unbeliever). Since for the Muslims a 
"Kafir" is an unbeliever, the Christians use also the same word for the Muslims. The result is that the "Kafirinization" of each other has only served to intensify and sustain the prejudices. In the Northern part of Nigeria, the colonialists felt that the Hausa-Fulani people were imbued with leadership qualities and this thinking took root in the minds of the Hausa-Fulani to the point of feeling that the principles and values of their religion must be applied in governance. This explains why some of them consider the Sharia superior to the constitution of the Federal Republic of Nigeria. Since the Hausa-Fulani were at the helm of affairs in terms of governance in the north, conversion to Islam became a ticket for the upward mobility towards socio-economic and political relevance within the northern political landscape.

The incursions of the military in the political arena further added fuel to these frustrations. Buhari and Idiagbong (1984-1985) ensured that "Islamic Penal Laws" were amended in the 1979 Constitution to "Sharia Law" Babangida (19841993) took Nigeria to the Organization of Islamic Conference (now Organization of Islamic Corporation -OIC). Abacha (1993-1998) ensured that Nigeria attended the OIC as full members and also introduced the Islamic banking system. Abubakar (1998-1999) adopted Babangida and Abacha's draft constitution on the Sharia Appeal Courts in the states in the 1999 Constitution (Tanko, 2007). Since then the North has continued to boil and with unabated violence.

According to Nmah and Nwadialor (2010), the relationship between the minorities and dominant HausaFulani ethnic groups in the north has been on the downward trend for some time now. In the First Republic, the issue concerning the agitation of the minorities was the right to a separation. The minorities wanted to free themselves from the domineering influence of the Ahmadu Bello - led Northern People's Congress (NPC). The NPC government, they contended, did not take into consideration their diverse cultural 
and religious character before proceeding under the premise of a monolithic north to foist linguistic and political structures upon them. This mistake sowed the seed of discord between Christians and Moslems in the north. Through the Native Authority System, the NPC government extended the powers of the Emirs, reduced the influence of Chiefs who were not Moslems and re-defined the local laws to suit the whims and caprices of the caliphate. A crisis arose between attempt to consolidate the hegemony of the Hausa-Fulani and the demands for its negation by the minorities. In order to perpetuate the hegemony of the caliphate, the Sarduana of Sokoto, the late Alhaji Ahmadu Bello, propounded the "gateway theory," reminiscent of the Monroe doctrine of the United States. In an address presented to the Minorities Commission in 1958, Ahmadu Bello outlined a number of measures to maintain the monolithic character of the North despite agitations to the contrary. The agitation of the minorities found expression in the Joseph Tarka - led United Middle Belt Congress (UMC) and the Borno Youth Movement (BYC). The Tiv riot of 1965 provided an insight into the deepening ethnoreligious crisis that ravaged the North in the early 60s. To Boko Haram's rules vis-à-vis Taliban (in Afahanistan and Pakistan), Al Shabab and the Sufi sectarian extremists (in Somalia), the following rules are implicitly the same and explicitly different from other Islamic fundamentalist groups on the basis of environment. Their general rules include:

i. Women are not expected to step outside their residence. If in any case they were to do so, they are not expected to go with fashionable clothes wearing many cosmetics and appearing in front of every man before the coming of Islam. All family elders and every Muslim have responsibility in this respect. Any woman that violates it will be threatened, investigated and severely punished as well as the family elders by 
the forces of the Religious Police (Munkrat). And again, such a woman will be cursed by the Islamic Sharia and should never expect to go to heaven.

ii. Female patients should go to female physicians. In case a male physician is needed, the female patient should be accompanied by her close relative.

iii. During examination, the female patients and male physicians both will be dressed with Islamic hijab.

iv. Male physicians should not touch or see the other parts of female patients except for the affected part.

v. Waiting room for female patients should be safely covered.

vi. The person who regulates turn for female patients' nurses and doctors should be a woman.

vii. During the night duty, in what rooms which female patients are hospitalized, the male doctor without the call of the patient is not allowed to enter the room.

viii. Sitting and speaking between male and female doctors are not allowed. If there be need for discuss, it should be done with hijab.

ix. Female doctors should wear simple clothes; they are not allowed stylish clothes or use of cosmetics or make-up.

x. Female doctors and nurses are not allowed to enter the rooms where male patients are hospitalized.

xi. The religious police are allowed to go for control at any time and nobody can prevent them.

xii. To prevent sedition and female uncovers (Be Hejabi). No drivers are allowed to pick up women who are using Iranian burga. In case of violation the driver will be imprisoned. If such kind of female is observed in the street, her house will be found and her husband punished. 
These groups advocate also for introduction of sharia to replace the secular constitution. To prevent beard shaving and its cutting, anyone who cuts his beard should be arrested and imprisoned until their beard gets bushy. To prevent idolatry, portraits in vehicles, shops, hotels, rooms and any other places should be abolished. To prevent gambling, a gambler is imprisoned for one month. And to eradicate the use of narcotics, addicts should be imprisoned and investigation made to find the supplier and the shop. The shop should be locked and the owner and user should be imprisoned and punished.

The Yusufiyya like the Taliban (from the Arabic word for student, "taleb"-are fundamentalist Sunni Muslims mostly from Afghanistan's Pashtun tribes) seek to establish a puritanical caliphate that neither recognizes nor tolerates forms of Islam divergent from their own. It scorns negotiation and democracy or any secular or pluralist political process as an offense against Islam. Boko Haram is a terrorist group characterized by robbery, raping and destruction of lives and properties (Kanu et al, 2011). As a result there is no need of the civil authority sheathing the sword for this sect or entering into any form dialogue with them. This group lacks democratic principles.

\section{Philosophical Doctrine and Ideology of "Maitatsine" and "Boko Haram" Sects (ta'ifa)}

Muhammed Marwa was an Islamic scholar who migrated from the town of Marwa in Northern Cameroun to the city of Kano in 1945. While in Kano he became an Islamic zealot concerned with the purification of Islam. He believed that Islam had been corrupted by modernization (Westernization) and the formation of the modern state. His constant preaching became very abusive and provocative, especially against established institutions like the emirate and the political class to the extent that the then Emir of Kano, Alhaji Sanusi Lamido, expelled him from Kano. Marwa found his way back to Kano in 1966, 
presumably after the death of Alhaji Sanusi. Between 19721979 Marwa was detained in prison several times for his provocative preaching and acts of lawlessness against the state. As Falola (1990) puts it:

He (Marwa) was a Quranic teacher and preacher. Forceful, persuasive and charismatic, he rebelled against many popular opinions among Kano Islamic circles, denouncing certain parts of the Holy Quran and even criticizing Prophet Muhammad. At one stage in his career, Marwa granted himself his most prestigious credential when he revealed himself to be an annabi: a prophet with divine power and a mission to save the world. He was alleged to have replaced the name of the prophet Muhammad with his own in personal copies of the Quran. He was opposed to most aspects of modernization and to all Western influence. He decried such technological commonplace as radios, wrist watches, automobiles, motorcycles, and even bicycles. Those who use these things or who read books other than the Qur'an were viewed as hellbound pagans (p.143).

Hitherto it was very obvious that Marwa exploited the dwindling economic situation as it is today in Nigeria and Almajeri system and was able to attract large followers amongst the commoners, who, unable to afford the basic necessities of life, became die-hard patriots of the sect and Marwa himself.

The leader of the Boko Haram movement, Yusuf, was a secondary school drop-out who went to Chad and Niger Republic to study the Qur'an. While in the two countries, he developed radical views that were abhorrent to Westernization and modernization. Like the late Maitatsine, Yusuf got back to Nigeria and settled in Maiduguri and established a sectarian group in 2001 known as the Yusufiyya, named after him. The sect (ta'ifa) was able to attract more than 280,000 members of school drop-outs and university graduates who were not gainfully employed across Northern Nigeria as well as in Chad 
and Niger Republic. These group of people believed that their state of hopelessness was caused by the government that imposed western education and failed to manage the resources of the country to the benefit of all. Yusuf began his radical and provocative preaching like Marwa against other Islamic scholars such as Jafar Adam, Abba Aji and Yahaya Jingir and against established political institutions.

The ideology and philosophy of the movement can best be understood by explicating the two words - "Boko" and "Haram". In Hausa language, the word "Boko" is an equivocal term which means either "Western" or foreign; while the "haram" is an Arabic derivative meaning "forbidden". Piecing the two words together "boko haram" means to forbid everything Western and Western education. The intent is to replace modern state formation with the traditional Islamic state, because Western values run contrary to Islamic values.

Umma Mahammadiya (Muslim faithful) and Dar-ulIslam (Islamic community) cannot be compromised in the face of Western influence. Evil in the society is as a result of the embrace of Western civilization, and in order to curb such evil an Islamic society must be entrenched by destroying modern state institutions. This philosophy goes hand in hand with the entrenchment of the Sharia law in the society. This accounts for the reason why police formations and government establishments and properties became the target of destruction by the sect. Ideologically, any member who fought and died for the course of an Islamic/Sharia state by destroying modern state formation and government establishment would automatically gain "Aljanna" (paradise or heaven).

The Christian heritage which has continued to worry the Muslims over the years, but have somehow been accepted as normal by the Christians include: 
i.

The fact of Saturday and Sunday being work-free days for the benefit of Christian worshippers while Friday enjoys no similar status.

ii. The present use of the Gregorian calendar named after Pope Gregory and is therefore of Christian origin while the Muslim Hijrah Calendar used officially by all Muslims is relegated in Nigeria.

iii. The $1^{\text {st }}$ of January, the beginning of the Gregorian calendar, is declared a public holiday while nothing is done for the Awwal-Muharram, that is, $1^{\text {st }}$ of Hahira in Hijrah Calendar (Kilani, 1998).

For the Muslims the point that needs to be made over the above stated issues is that the introduction of Sharia, Islamic Bank and Nigeria membership of organization of Islamic corporation (OIC) cannot change Nigeria into Islamic state.

\section{Conclusion and Recommendations}

Nigeria, with its large number of impoverished disenfranchised and devoutly Muslim young men, easy access to weapons and endemic corruption may seem to be the ideal breeding ground for anti-western radicals. The presence of an Al-Qaeda branch operating across the Sahara Desert in Mauritania, Morocco, Mali and Niger and Nigeria's porous borders' have sharpened such fears.

The New Testament maintains that the civil government has been established by God with responsibility for maintaining justice. This is why the government has a rightful duty to "bear the sword (Rom. 13:4), to be "a terror" to bad conduct, and thus to be "God's servant" to do "good" for its citizens (Rom. 13: 3-4). Part of this responsibility is acting as a "servant of God who carries out God's wrath on the wrongdoer" (Rom. 13:4). Therefore one of the primary duties of government is to protect its citizens even through the use of force ("the sword") 
if that is necessary in order to restrain evil. In the Old Testament God says that rulers must "give justice to the weak" and must "deliver them from the hand of the wicked" (Ps. 82: 3-4).

This is the justification for army, police forces and other relevant security outfits that protect citizens from any harm that would come from others within our nation-Nigeria. And this responsibility from God also provides justification for nations such as USA and European countries to engage in armed conflict ("to bear the sword") in order to protect their citizens from evildoers (the Talibans, Al Qaeda, and other Islamic extremists who would attack them from other outside or within their countries. This includes also a defense against armies sent by other nations when those armies and nations are "those who do evil" (1Pet. 2:14) in the pursuit of such a war.

Several wars in the Old Testament fall under this category of a war of defense against evil aggression such as Abraham's war to rescue Lot in Genesis 14:1-16; Saul's war against the Ammonites in 1Samuel 11:1-11; and Gideon's war to defend Israel against the Midianites in Judges 6-7. Therefore it should not be thought inconsistent in the OT for God to command people to go to war (Deut. 20). The crusade ethic treats war as the most effective means for destroying all resistance to establishing some idealistic vision of social order. It does so by religious authority; it is led by a religious figure such as a prophet, pope, or imam; it accepts no compromise; it spares no prisoners; it sets no limits on force, its sends soldiers into battle with zeal; it ignores all odds; it demonizes opponents; it distinguishes only between friend or foe not between combatants and noncombatants; it never surrenders; and it never ceases so long as opposition exists. But while God does order wars of crusade in the OT such as Moses war of vengeance against the Midianites in Numbers 31, and Joshua's conquest of Canaan in the book of Joshua. The just war ethical tradition arises from both biblical and classical sources. In the 
Bible, just war principles can be found in rules revealed for engaging enemies outside the territory of the Promised Land (Deut. 20: 1-20), in God's judgment of war actions taken by the Gentile nations around Israel (Amos), and in the regard Jesus had for moral wisdom relating to the way kings go to war (Luke 14:31).

In as much as I have to acknowledge that things are not well in Nigeria in respect to unemployment, corruption and mal-administration, it is not peculiar to Nigeria because it is also experienced in Europe and Middle East. That notwithstanding I have to make the following recommendations. Thus,

i. Nigerians should imbibe the culture of religious tolerance, trust and dialogue in inter-ethnic relations.

ii. Federal government/Nigerians should promote patriotism among themselves.

iii. There should be reduction in the pay packet of the politicians to avoid the bad ones from sponsoring terrorists as political thugs.

iv. There should be confidentiality for intelligence report given to the security outfits.

v. There should be honest fighting of corruption in Nigeria.

vi. Unemployment among the youths often has deleterious effect on community morals and spirit. This army of unemployed could easily be lured into any negative tendencies and are in fact ready to be recruited for any anti-social activity. The security agencies in the country hardly derive the benefit from public contributions leading to arrests and necessary legal processes because in this country, an informant of a crime could end up a victim. Consequently government should promote religious values, agriculture and entrepreneurship in communities and 
schools; this will help to reduce religious extremism in Nigeria. Federal, state and local government/council should provide employment for the honest serious minded youths. Safety and security needs include physical safety from harm and the elements as well as financial security (Lamberton and Minor-Evans, nd).

vii. Christian and Islamic religions to be made compulsory at senior secondary certificate examination.

viii. Security agencies should always proffer solutions for non-existing evil before it occurs.

ix. Security outfits should avoid addressing criminalities when they have already taken place.

x. The security officers should be degree certificate holders as minimum certificate for security officials.

xi. Security officials should always share security ideas with countries with similar problems or with those countries that have overcome such security challenges.

xii. Federal government should establish institution for criminalities for the army, police and other security outfits. This will enable them to study crimes before they occur.

xiii. The security agents should be adequately equipped with modern sophisticated weapons.

xiv. The national security agencies should infiltrate into the rank and file of this group and the similar ones in order to monitor their activities and nip it in the bud their violent crimes.

Xv. For the sake of Nigerian survival, religious groups should not oppose any legitimate demand of the other so far as such demands do not constitute a denial of their own rights. 
xvi. Mutual understanding should replace strife between Muslims and Christians in Nigeria to make Nigeria a great nation in the $21^{\text {st }}$ century.

xvii. In our annual national and state budgeting, we should consider the need to maintain the military and police in the state of combat readiness; the need to provide enough funds to take care of the socio-economic problems facing our country; and the threat of external aggression.

xviii. There should be adequate compensation to an informant for any valuable information regarding security threat.

xix. Forensic investigators and criminal profilers of hostage negotiators among the security agencies should be adequately trained.

xx. There should be proper welfare and retirement benefits for security officials.

xxi. The national assembly should reduce its jumbo salary so that federal government can have enough funds to create jobs for the teeming graduate youths.

xxii. There should be enabling law to empower special security agencies to engage in phone hacking as a measure to contend insecurity.

xxiii. First and foremost, the security agencies should be well taken care of in the way of enhancing their salaries coupled with comprehensive life insurance. This measure will take care of any security official that dies in the course of action to compel the government to build a house for the late official and also award scholarship to his subsiding children. This approach will strengthen the mind of the police and the like to confront armed robbers, members of Boko Harram (Yusufiyya movement), and the Maitatsine group, kidnapping gang, Niger Delta militants and other insurgent groups that fight to die. 
xxiv. Security agent should be trained and be retrained.

$\mathrm{xxv}$. The identity of any security agency sources (that is informers/informants) should be adequately protected, and adequately compensated. This will encourage good citizens to come forward to pass the necessary insecurity information to appropriate security agencies.

xxvi. There should be cleansing of bad politicians, police men and other bad security agent officials who are directly or indirectly collaborating with these criminals.

xxvii. Federal government should encourage and to co-opt community vigilantes and traditional rulers on to the security matters.

xxviii. Editing of international news broadcast in Nigeria is imperative for security purposes.

Terrorism in the name of religion is a violent mad approach to issues of conflict. It is sinful and satanic for one or group of people to use terrorism in the name of religion to pursue an inordinate ambition whether religious, political or economic. All religious groups or sects that apply terrorist method as a modern Jihad, Zionism, Crusade and the like seize to be divine religious groups or sects and therefore are diabolic in nature and action. The adherents of these groups should be regarded as terrorists or criminals and consequently government should not enter into dialogue with such faceless groups. They are breakers of divine law.

Divine religion can not subscribe to terrorism. Taliban, Al Shabab, Al Qaeda and Boko Haram are terrorist groups. More often than not they target establishing an Islamic state. For them to achieve that, they carry out their nefarious terrorist attacks an government establishments, western countries, markets, police stations, stadiums, airports, recreation clubs, schools, government officials and individuals that are against 
them. Hence sheathing the sword for Boko Haram and similar groups shall result to national insecurity.

*Patrick Nmah is a Senior Lecturer in the Deaprtment of Religion and Human Relations, Nnamdi Azikiwe University, Awka. 


\section{References}

Boer, H. R. (2006). A brief history of Islam. Ibadan: Daystar.

Enuka, C. (2010). Terrorism: Theories and effects on international security. Arts \& Humanities Quarterly, Volume 5, October, Number 4, pp. 58-66.

Falola, T. (1998). Violence in Nigeria: The crisis of religious politics and secular ideologies. New York: University of Rochester.

Fromkin, D. (2004). The strategy of terrorism. Journal of Foreign Affairs, Vol. 11, No. 53.

Huntington, S.P. (2003). The clash of civilization and the remarking of the world order. New York: Simon and Schuster.

Kanu, D. et al (2011, July 5). Boko Haram Kills four, steals $\mathrm{N} 21.5 \mathrm{~m}$ LG salaries in Borno. Daily Independent Newspaper, pp. 1-2, Vol. 10, No. 22081.

Khuri, F.I. (1990). Imam and Emirs: State, religion and sect in Islam. London: Saqi.

Kilani, A.R.O. (1998). Analysis of implications of Nigeria Membership Organization of Islamic Conference. In E.S. Akama (Ed.), Religion in Contemporary Nigeria: Some topical issues (pp. 99-110), Owerri: Springfield.

Kukah, M.H. (1994). Religion, power and politics in Northern Nigeria. Ibadan: Spectrum.

Lamberton, L. and Minor - Evans, L. (Ed.). (ND). TitleNew York: McGraw.

Nmah, P. E. (2004). Basic \& Applied Christian Ethics: An African Perspective. Onitsha: Gucks Systems In't.

Nmah, P.E. \& Nwadialor, K.L. (2010). The history of Christianity \& Islamic spirituality in Nigeria: A global fundamentalist approach. In A.B.C. Chiegboka, T.C. 
Utoh-Ezeajugh and G.I. Udechukwu (Eds.), The humanities \& globalization in the third millennium (pp. 278-284). Nimo: Rex Charles \& Patrick.

Okeke, C.C.S. (1990). Conceptual problems of defence expenditure estimation in Nigeria. In C.C.S. Okeke (Ed.), Defence, patriotism and national development (pp. 16-43). Onitsha: Veritas.

Suberu, R.T. (2009). Religion and institutions: Federalism and the management of conflict over Sharia in Nigeria. Journal of International Development, 21, pp. 547-560.

Tanko, P.B. (2007). Conflict in Northern Nigeria: Toward a resolution. Koinonia Journal, Vol. 3 No. 3, pp. 99-128.

Tasker, R.V.O. (1981). The gospel according to St. Matthew. Michigan: The Tyndale.

Tristam, P. (1996). Taliban rules, decrees, laws and prohibitions. Retrieved on 04.07.11 from http://middleeast.about.com.

Tucker, R.C. (Ed.). (1978). The Marx-Engel Reader. New York: Norton.

Weber, M. (2002). The protestant ethic and the spirit of capitalism. Los Angeles: Roxbury.

Wilson, B. (1982). Religion in sociological perspectives. Oxford: Oxford University Press. 